\title{
Nanostructured electrocatalytic materials and porous electrodes for direct methanol fuel cells
}

\author{
Meng Wang, Xindong Wang *, Ming Chen, Zhaoyi Yang, Chaozhen Dong \\ Department of Physical Chemistry, School of Metallurgy and Ecological Engineering, University of Science and Technology Beijing, Beijing 100083, China
}

\section{A R T I C L E I N F O}

Article history:

Received 22 April 2016

Accepted 27 May 2016

Published 5 July 2016

\section{Keywords:}

Catalyst

Porous electrode

Methanol crossover

Electrocatalytic performance

Membrane electrode assembly

Direct methanol fuel cells

\begin{abstract}
A B S T R A C T
Direct methanol fuel cells (DMFCs) are promising for use in portable devices because of advantages such as high fuel energy density, low working temperature and low emission of pollutants. Nanotechnology has been used to improve the performance of DMFCs. Catalytic materials composed of small, metallic particles with unique nanostructure supported on carbons or metal oxides have been widely investigated for use in DMFCs. Despite our increased understanding of this type of fuel cell, many challenges still remain. This paper reviews the current developments of nanostructured electrocatalytic materials and porous electrodes for use in DMFCs. In particular, this review focuses on the synthesis and characterization of nanostructured catalysts and supporting materials. Both computational and experimental approaches to optimize mass transportation in porous electrodes of DMFCs, such as theoretical modeling of internal transfer processes and preparation of functional structures in membrane electrode assemblies, are introduced.
\end{abstract}

(C) 2016, Dalian Institute of Chemical Physics, Chinese Academy of Sciences. Published by Elsevier B.V. All rights reserved.

\section{Introduction}

Direct methanol fuel cells (DMFCs) have been attracting extensive attention for many years as alternative energy devices. DMFCs are promising for use in portable electronic devices and field equipment, as well as light electric vehicles, because of their high fuel energy density, simplicity, rapid start-up, easy fuel recharging and low pollution. California-based Oorja Protonics launched its "ultra-powerful" DMFC technology in 2008. This company has also unveiled a variety of commercial products, such as Oorja Model 3 for the materials handling market and Oorja Model T-1 for stationary applications. Danish company IRD also has developed 500-W and 800-W DMFCs for use in lighthouses and telecommunication towers.

The maximum thermodynamic voltage of a DMFC at $25^{\circ} \mathrm{C}$ is $1.18 \mathrm{~V}$, as defined by its electrocatalytic redox reactions [1]:
Anode reaction:

$$
\mathrm{CH}_{3} \mathrm{OH}+\mathrm{H}_{2} \mathrm{O}=\mathrm{CO}_{2}+6 \mathrm{H}^{+}+6 \mathrm{e}^{-} ; E_{\mathrm{a}}=0.046 \mathrm{~V}
$$

Cathode reaction:

$$
\frac{3}{2} \mathrm{O}_{2}+6 \mathrm{H}^{+}+6 \mathrm{e}^{-}=3 \mathrm{H}_{2} \mathrm{O} ; E_{\mathrm{c}}=1.23 \mathrm{~V}
$$

Overall reaction:

$$
\mathrm{CH}_{3} \mathrm{OH}+\mathrm{H}_{2} \mathrm{O}+\frac{3}{2} \mathrm{O}_{2}=\mathrm{CO}_{2}+3 \mathrm{H}_{2} \mathrm{O} ; E_{\text {cell }}=1.18 \mathrm{~V}
$$

However, because of the different types of voltage loss caused by the complexity in DMFCs, the actual cell voltage is lower than the theoretical value. In particular, methanol crossover (MCO) from the anode to the cathode causes a mixed potential in the cathode, making the overall cell voltage much lower than that of hydrogen fuel cells. Although considerable improvement has been realized, DMFCs are still far from widespread commercial application. At present, electrocatalytic materials are a major obstacle limiting DMFC technology. Con-

\footnotetext{
*Corresponding author. Tel/Fax: +86-10-62332651; E-mail: echem@ustb.edu.cn This work was supported by the National Natural Science Foundation of China (51274028). 
ventional Pt catalysts suffer from several issues including catalyst deactivation, low catalytic efficiency and high cost. Thus, current research focuses on the development of inexpensive catalysts that display high stability, durability, and performance.

Besides the catalysts, DMFCs also face issues related with the microstructure and electrochemical characteristics of the membrane electrode assembly (MEA), where the chemical energy is converted to electrical energy by electrocatalytic redox reactions. MEAs are typically composed of an anode diffusion layer (DL), an anode catalyst layer (CL), a proton exchange membrane (PEM), a cathode CL, and a cathode DL. MEAs provide a complex conductive environment for electron/proton conduction, reactant/product transportation and interfacial redox reactions. Normally, methanol diffuses into the anode DL from the anode flow field, and reaches the anode CL, where it takes part in the methanol oxidation reaction (MOR). Excess methanol will be transported to the cathode by osmotic pressure and electromigration across the PEM, and then reacts with oxygen $\left(\mathrm{O}_{2}\right)$ as soon as it arrives at the cathode. Although the exact kinetics of this process are the subject of debat, the end result is a decrease of the cell voltage. At the cathode, $\mathrm{O}_{2}$ from the surrounding air is transferred through the cathode DL to the cathode CL, where it is reduced to water. At the same time, free electrons from the anode reactions flow through the external circuit to the cathode, which allows the reaction at the cathode to continue. Before the electrons reach the current collector, they must be able to flow through the cathode CL and DL. By optimizing every layer in a MEA, limitations such as transport and management issues and MCO can be overcome, and conduction and distribution can be enhanced [2].

\section{Nanostructured electrocatalytic materials for use in DMFCs}

The catalytic efficiency can be enhanced by optimizing the structure or composition of electrocatalytic materials. For instance, numerous studies have shown that constructing an appropriate porous network or ordered nanoparticle array in the CL can lead to enhanced catalytic performance and improved Pt utilization because of an increase of electrochemically active surface area (EASA) [3]. Regarding composition modification, many researchers have focused on introducing other metals or metal oxides into Pt catalysts to modify their interface electronic state $[4,5]$. During such modification, the ligand effect can influence the poison tolerance of Pt by weakening the interaction between $\mathrm{Pt}$ and some adsorbates such as protons $\left(\mathrm{H}^{+}\right)$, hydroxide ions $\left(\mathrm{OH}^{-}\right)$or adsorbed carbon monoxide ( $\left.\mathrm{CO}_{\mathrm{ads}}\right)$, and thus improve catalytic efficiency. For example, it is well known that Pt-Ru bimetallic catalysts can activate $\mathrm{H}_{2} \mathrm{O}$ at lower potential than $\mathrm{Pt}$, the adsorbed $\mathrm{OH}^{-}$species on $\mathrm{Ru}$ can oxidize the $\mathrm{CO}_{\text {ads }}$ on the surface of the Pt atoms to $\mathrm{CO}_{2}$ and thus increase the anti-poisoning ability of Pt; this process is usually called the bifunctional mechanism [6].

\subsection{Pt-based nanostructured catalysts}

The three-dimensional (3D) network structure is considered suitable for constructing high-efficiency CLs because it facilitates internal transport by providing continuous passages and decreasing diffusion distances. The porous structure composed interspaces between separated branches can also provide sufficiently accessible active sites at interfaces to allow electrocatalytic reactions. The gaps between nanoparticles have been proved effective at preventing grain rearrangement and growth, improving the working life and durability of fuel cells [7]. Among various catalysts, Pt-based catalysts with advanced nanostructures are of particular interest for use in DMFCs.

As an example of a CL with a 3D network structure, Yamauchi et al. [8] used a soft template method with lyotropic liquid crystals (LLCs) to form highly ordered mesoporous materials with lamellar, two-dimensional hexagonal, 3D cubic, and other nanostructures. They also developed a very simple one-step method to prepare $\mathrm{Pt}$ nanodendrites at room temperature within 5 min using block copolymer as a structure-directing agent [9]. Transmission electron microscopy (TEM) images of these Pt nanodendrites are shown in Fig. 1. The block polymer with amphiphilic nature mediated the growth of branched nanostructures through physical and chemical interactions with Pt precursors. The Pt nanodendrites displayed not only a large active Pt surface area, but also favorable electrochemical performance. The mass-normalized current densities for $\mathrm{Pt}$ nanodendrites and commercially available Pt black were 0.52 and $0.11 \mathrm{~A} / \mathrm{mg}$, respectively, in the positive direction sweep. The current density of the Pt nanodendrites was 4.7 times higher than that of Pt black.

Recently, Fan et al. [10] reported a one-pot hydrothermal synthesis of porous Pt-Cu alloy networks using the block copolymer Pluronic-F127 as a structure-directing agent. A scan-

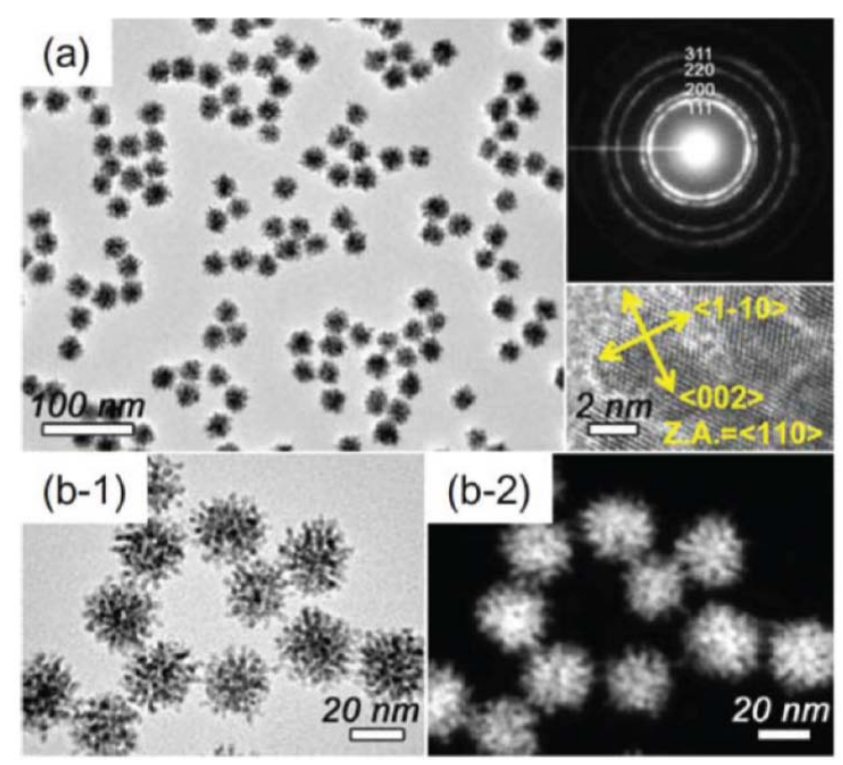

Fig. 1. (a, b-1) TEM images of Pt nanodendrites at low magnification. The inset images in (a) are selected-area electron diffraction patterns recorded for several particles and crystalline lattice fringes observed on the particle edge. (b-2) High angle annular dark field scanning transmission electron microscopy image of the same region as (b-1) [9]. 
ning electron microscopy (SEM) image of a $\mathrm{Pt}_{53} \mathrm{Cu}_{47}$ network is provided in Fig. 2. The as-prepared $\mathrm{Pt}-\mathrm{Cu}$ alloy exhibited a unique 3D hierarchical porous network structure consisting of numerous interconnected nanodendrites. Remarkably, this network structure mostly presented in the form of monodisperse metal nanoparticles. In this synthesis, ethylene glycol served as a weak reducing agent to allow slow growth of Pt-Cu alloy nanostructures. The block copolymer was used as amphiphilic molecules to adjust the structure formation, making it important in the formation of porous Pt-Cu alloy nanostructures. In addition, the reduction kinetics substantially affected the nucleation, growth and resulting structure of the $\mathrm{Pt}-\mathrm{Cu}$ alloys. Because of its porous network structure composed of unique nanodendritic building blocks, the $\mathrm{Pt}_{53} \mathrm{Cu}_{47}$ alloy catalyst exhibited superior electrocatalytic performance toward the MOR compared with that of $\mathrm{Pt}_{73} \mathrm{Cu}_{27}$ and Pt black (Fig. 3).

Similarly, various nanostructured Pt-Pd catalysts have been studied to obtain higher surface area and lower mass transfer resistance [11]. Among such catalysts, those with hollow porous structures have attracted special interest. Recently, Qiu and colleagues [12] developed a general electrostatic attraction-directed layer-by-layer assembly approach to construct novel Pt-Pd alloy hollow porous nanospheres (HPNSs) using $\mathrm{SiO}_{2}$ nanospheres as templates (Fig. 4). They found that the strong electrostatic attraction between charged species during the synthetic process played important roles in the homoge-

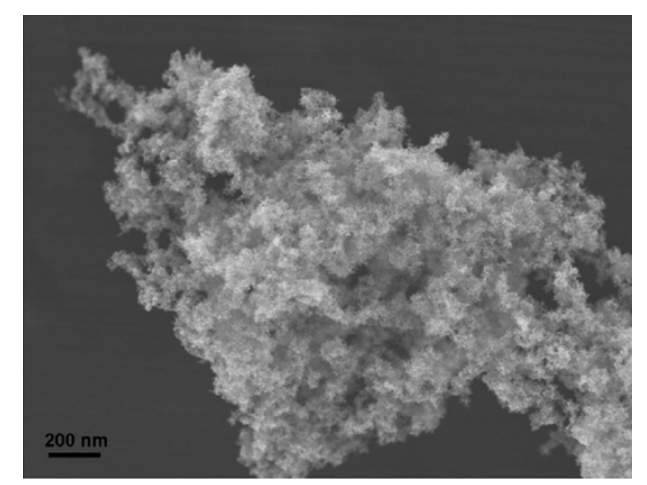

Fig. 2. SEM image of $\mathrm{Pt}_{53} \mathrm{Cu}_{47}[10]$.

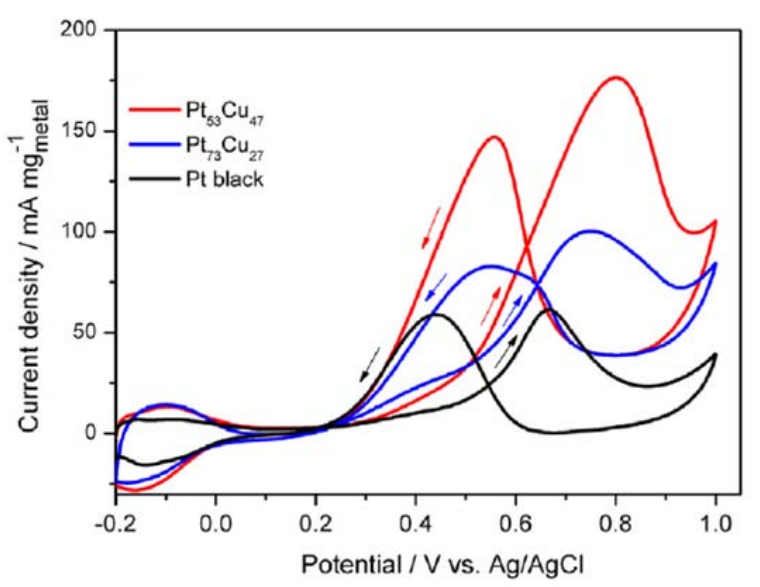

Fig. 3. CV curves of Pt-based catalysts measured in $0.5 \mathrm{~mol} / \mathrm{L}$ sulfuric acid $+1 \mathrm{~mol} / \mathrm{L}$ methanol at an applied potential of $0.7 \mathrm{~V}$ [10].

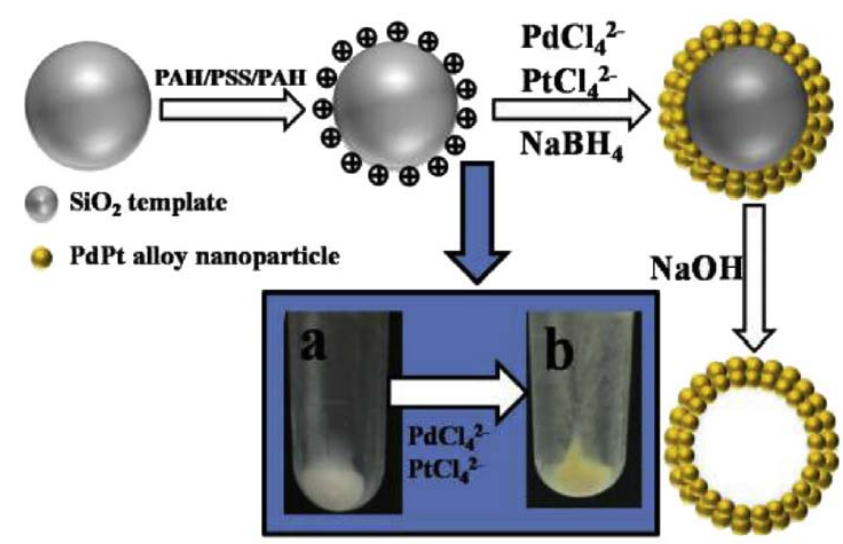

Fig. 4. Schematic representation of the synthesis of Pt-Pd hollow porous nanospheres (HPNSs). Inset are photographs of PAH/PSS/PAH-modified $\mathrm{SiO}_{2}$ solution after centrifugation (a) andPdCl${ }_{4}^{2-}$ and $\mathrm{PtCl}_{4}{ }^{2-}$ with $\mathrm{PAH} / \mathrm{PSS} / \mathrm{PAH}$-modified $\mathrm{SiO}_{2}$ solution after centrifugation (b) [12].

neous, compact deposition of alloy nanoparticles on the surface of the $\mathrm{SiO}_{2}$ templates and subsequent formation of alloy HPNSs. Because of their unique compositional and structural features, the optimized Pt-Pd HPNSs displayed markedly enhanced electrocatalytic performance in the MOR in terms of catalytic activity and durability compared with that of both commercial Pt black and Pd black catalysts. The peak polarization current of Pt-Pd HPNSs was $198.7 \mathrm{~mA} / \mathrm{mg}$, which is much higher than those of Pd black (45.7 mA/mg) and Pt black (120.3 mA/mg). The promising electrocatalytic performance of the Pt-Pd HPNSs makes them a suitable anodic catalyst for DMFCs.

Besides these template techniques, dealloying is another attractive method to prepare nanostructured catalysts. In dealloying, an additional metal is selectively dissolved from an alloy precursor to give a bimetallic catalyst with a self-supporting porous nanostructure [13]. Sun et al. [14] reported a novel ultrafine nanoporous $\mathrm{Pt}-\mathrm{Cu}$ alloy with a $\mathrm{Pt}: \mathrm{Cu}$ stoichiometric ratio of $3: 1$ (denoted np- $\mathrm{Pt}_{3} \mathrm{Cu}_{1}$ ), which was prepared by mechanical alloying and subsequent two-step chemical dealloying (Fig. 5). The specific activity of the np- $\mathrm{Pt}_{3} \mathrm{Cu}$ alloy was much higher than that of a reference $\mathrm{Pt} / \mathrm{C}$ catalyst. The peak current density of the np- $\mathrm{Pt}_{3} \mathrm{Cu}$ alloy in the positive scan in cyclic voltammetry (CV) measurements in $0.5 \mathrm{~mol} / \mathrm{L}$ sulfuric acid and 0.5 mol/L methanol solution at $25^{\circ} \mathrm{C}$ was $1.38 \mathrm{~mA} / \mathrm{cm}^{2}$, which was about 3.5 times that of $\mathrm{Pt} / \mathrm{C}\left(0.39 \mathrm{~mA} / \mathrm{cm}^{2}\right)$.

These Pt-based catalysts with 3D network nanostructure generally exhibited improved reaction kinetics and catalytic efficiency compared with those of reference materials. This is because the 3D networks provided plentiful active sites and led to reinforced structural stability and extended working durability originating from their enhanced resistance to Ostwald ripening, dissolution and aggregation. Complex components seem to be promising to increase the catalytic activity of materials, and the use of nanostructures is becoming a new trend to overcome the major limitations of DMFCs [15].

\subsection{Supporting materials}




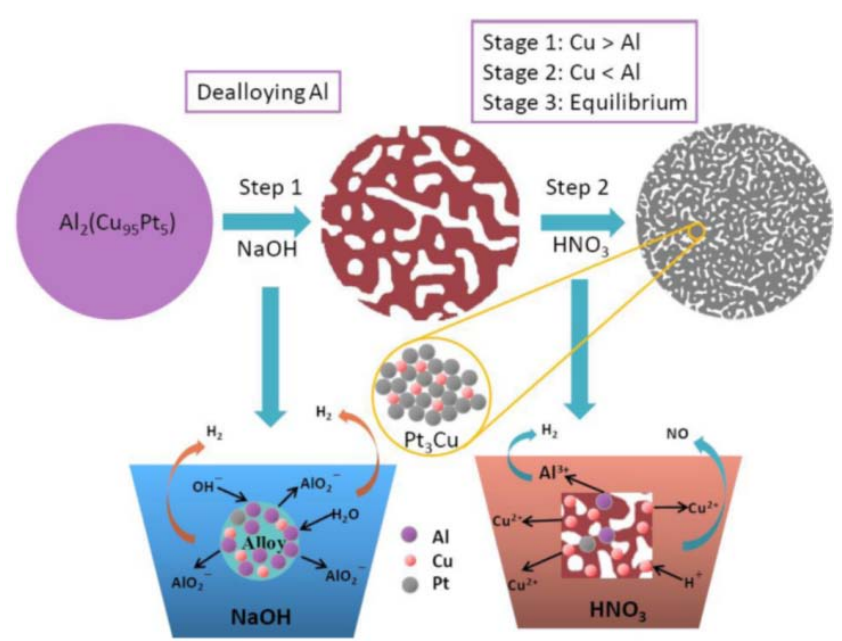

Fig. 5. Schematic illustration outlining the fabrication process of a nanoporous $\mathrm{Pt}_{3} \mathrm{Cu}$ alloy by two-step dealloying [14].

Numerous researchers have used carbon supporting materials in their studies. The results have generally indicated that the introduction of nanostructured carbon materials into CLs can lower the reaction charge transfer resistance, improve mass transfer efficiency and decrease the usage of noble metal catalysts [16,17]. Recently, hollow carbon materials with a core-shell structure have attracted extensive attention for use in CLs $[18,19]$. For example, a periodically ordered bimodal porous carbon (POBPC) framework with a hollow core-mesoporous shell structure designed to support a Pt-Ru catalyst exhibited much higher specific activity in the MOR than the counterpart with commercial E-TEK [20]. This result was attributed to the high EASA and well-developed interconnected macroscale and mesoscale bimodal porosity of the POBPC framework, which allowed facile diffusion of reactants and products to and from the CL. Related reports had widely assumed that in MEAs, the mesopores and micropores act as mass transfer passages and the main reaction space for the MOR and oxygen reduction reaction, and the other macropores act as a pathway into the interior reaction sites.

To further improve the catalytic efficiency of nanostructured carbon-supported catalysts, many studies have focused on introducing heteroatoms to overcome the adverse effects caused by the relatively inert surface state of carbon [21,22]. Among these advanced materials, various $\mathrm{N}$-doped carbon supports have received extensive attention. Many researchers attributed the enhancement in catalytic efficiency caused by $\mathrm{N}$ doping to the resulting change of surface electron donor/acceptor characteristics, and thus suggested that $\mathrm{N}$-doped nanostructured carbon materials could be ideal catalyst-supporting materials for DMFCs [23,24]. Zhang et al. [25] successfully prepared hierarchical $\mathrm{N}$-doped porous hollow carbon spheres (HNPHCSs) through in situ oxidation polymerization using polyaniline (PANI) as the precursor (Fig. 6). The physical and chemical characterization results indicated that the HNPHCSs have an interconnected bimodal pore system with a thin mesoporous shell and hollow macroporous core, which is potentially important for use as a supporting material.

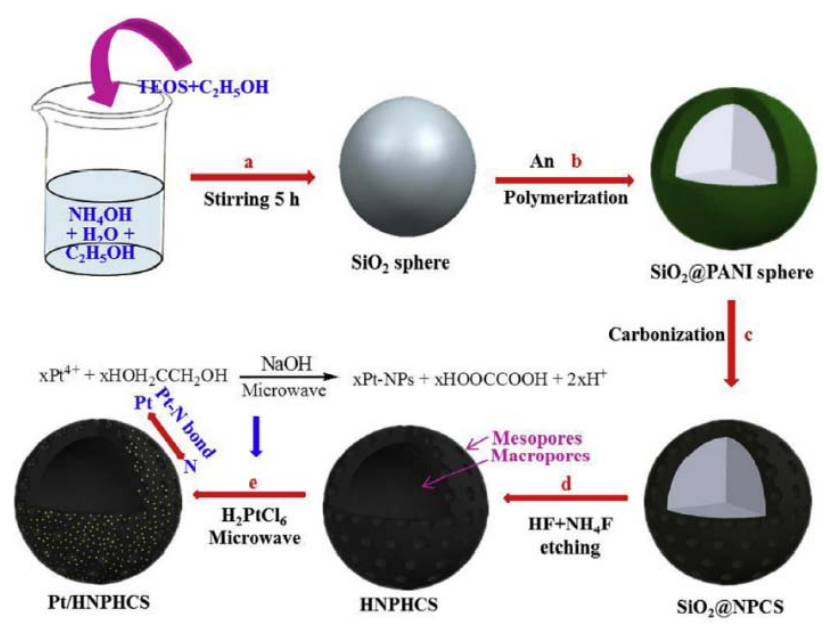

Fig. 6. Schematic route to prepare Pt nanoparticles supported on hierarchical N-doped porous hollow carbon spheres (HNPHCs) [25].

Conductive polymer supporting materials can also help to decrease the content of $\mathrm{CO}_{\text {ads }}$ on the surface of Pt particles and improve catalytic efficiency. Conductive polymers such as PANI have excellent electrochemical properties in the MOR, so many researchers have paid them great attention for a long time [26,27]. Hybrid structures containing PANI and its derivatives are currently attracting increasing interest because of their superior performance to PANI alone [28]. For example, Shah and co-workers [29] coated a PANI/poly-ortho-aminophenol (POAP) bilayer structure on Pt electrodes for use in the MOR in DMFCs by electropolymerization. CV measurements revealed that the maximum anodic current of PANI/POAP deposited on a Pt electrode was 1.3 times higher than that of a reference POAP-Pt electrode. Furthermore, electrochemical impedance spectroscopy (EIS) showed that with increasing upper potential, the conductivity and capacitance of the PANI/POAP-Pt electrodes increased because of the desorption and oxidation of $\mathrm{CO}_{\text {ads }}$ to $\mathrm{CO}_{2}$. Overall, conductive polymers with hybrid structures containing PANI and its derivatives can be considered as good supporting materials for CLs in DMFCs.

Pt-based catalysts are nearly irreplaceable for methanol electrocatalytic oxidation at normal temperature in an air atmosphere. However, a self-poisoning process on the Pt surface caused by reaction intermediates such as $\mathrm{CO}_{\text {ads, }}$ which are formed during stepwise dehydrogenation of methanol, the catalytic properties of $\mathrm{Pt}$ are unstable. Metal oxides can change the surface electronic state of $\mathrm{Pt}$ particles and provide reactive oxygen species to react with $\mathrm{CO}_{\mathrm{ads}}$, suppressing catalytic poisoning of Pt. Research has also indicated that the coexistence of multiple valence states in metal oxides is beneficial to electron transport during redox reactions [30].

As an example of how a metal oxide can affect the properties of $\mathrm{Pt}$, addition of $\mathrm{CeO}_{2}$ can enhance the catalytic activity and stability of Pt-based catalysts by increasing the oxygen content on the catalyst surface [31]. Recently, Wang et al. [32] proposed a 3D Pt-rod-shaped $\mathrm{CeO}_{2}$ /graphene sheet (Pt- $\mathrm{NRCeO}_{2} / \mathrm{GN}$ ) catalyst to improve the electrocatalytic properties of $\mathrm{Pt}$ in the MOR. They synthesized rod-shaped $\mathrm{CeO}_{2}$ on graphene sheets 
using an in situ growth method. TEM images of Pt-NRCeO $/$ GN are shown in Fig. 7. The rod-shaped $\mathrm{CeO}_{2}$, which acted as a spacer to prevent graphene stacking, exposed a large amount of Pt particles in the effective reaction region to realize performance improvement. In electrochemical tests, the Pt-NRCeO $/$ GN catalyst showed a higher ESA value $\left(72.6 \mathrm{~m}^{2} / \mathrm{g}\right)$ and larger catalytic current density (498 mA/mg) for methanol oxidation than those of commercial catalysts.

$\mathrm{SnO}_{2}$ is also of particular interest to prevent Pt catalyst poisoning because of its highly efficient $\mathrm{CO}_{\text {ads }}$ oxidation caused by facile oxygen species transmission [33]. Pt-SnO 2 catalysts on different nanostructured carbon supports exhibited superior electrochemical performance compared with that of commercial Pt/C catalyst $[34,35]$. Recently, the catalytic activity of $\mathrm{Pt}-\mathrm{SnO}_{2}$ catalysts doped with a third element in the MOR has been investigated. The indium-doped $\mathrm{Pt}-\mathrm{SnO}_{2}$ catalysts developed by Feng et al. [36] exhibited almost twice the current density of undoped samples under the same experiment conditions. The same group also prepared Mo-doped $\mathrm{SnO}_{2}$-Pt catalysts for use in the MOR. Compared with the binding energies of the $\mathrm{Pt} / \mathrm{C}$ counterpart, all the binding energies of $\mathrm{Pt}$ in the reported $\left(\mathrm{MoO}_{3}\right)_{\mathrm{mSnO}}$ - $\mathrm{Pt} / \mathrm{C}$ catalysts were shifted to higher values. Some researchers proposed that these enhancements originated from the downshift of the $d$-band center of Pt, which led to a weakened interaction between Pt and the adsorbed reaction intermediates [37].

Among various metal oxides, $\mathrm{TiO}_{2}$ has received the most interest because of its large catalysis promoting effect and high working durability in DMFC environments. As an effective method to improve the electronic conductivity and EASA of Pt catalysts, a hybrid supporting material for Pt-based catalysts consisting of $\mathrm{TiO}_{2}$ and nanostructured carbon was developed $[38,39]$. Characterization of the supported catalyst revealed that the support could efficiently improve the electrocatalytic performance of Pt in the MOR.
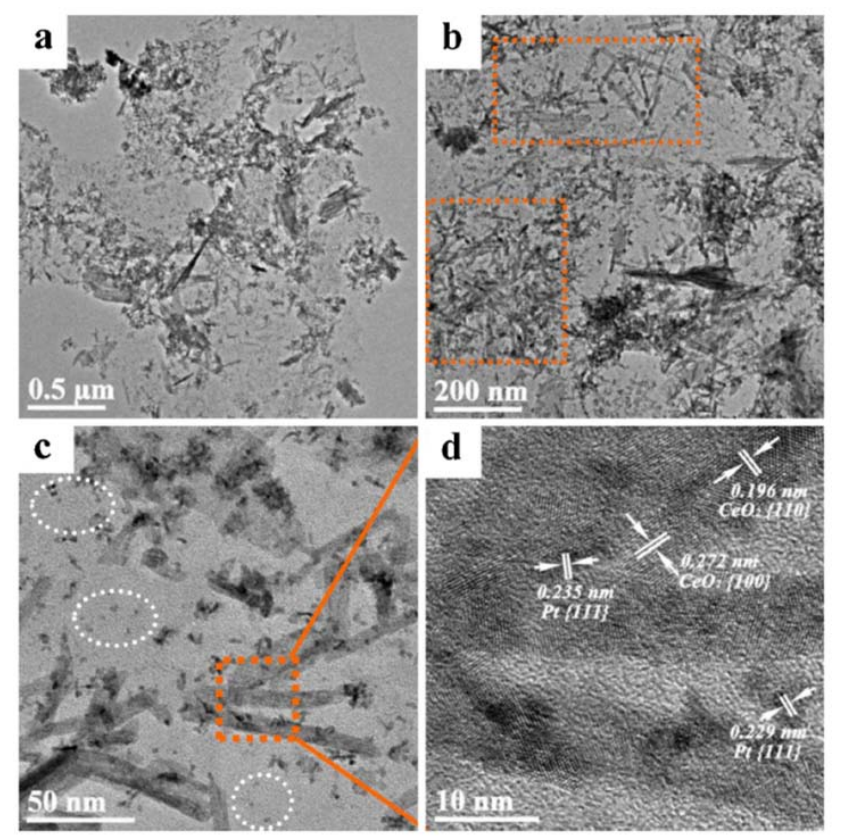

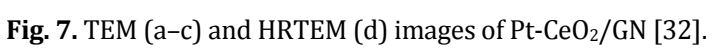

To obtain $\mathrm{Pt} / \mathrm{TiO}_{2}$ catalysts with specific morphology and advanced performance, various methods to prepare $\mathrm{Pt} / \mathrm{TiO}_{2}$ materials, such as electrospinning, electric deposition, coating pyrolysis, physical or chemical vapor deposition, and magnetron sputtering, have been investigated [40,41]. For instance, a $\mathrm{Pt} / \mathrm{TiO}_{2}$ nanofiber $\left(\mathrm{TiO}_{2} \mathrm{NF}\right)$ catalyst prepared by electrospinning was found to display highly effective catalysis under DMFC conditions [42]. This is because the surface and pore structure of $\mathrm{TiO}_{2} \mathrm{NF}$ led to facile transportation of reactants and products. In addition, the deactivation caused by $\mathrm{CO}_{\text {ads }}$ was generally well suppressed by the $\mathrm{Pt} / \mathrm{TiO}_{2} \mathrm{NF}$ catalyst. The assurance of sufficient oxygen supply from the $\mathrm{TiO}_{2}$ support has been attributed as the cause of the improvement of catalytic activity. However, to avoid the high electronic resistance and superfluous coverage of $\mathrm{OH}^{-}$caused by excess $\mathrm{TiO}_{2}$, the $\mathrm{Pt} / \mathrm{TiO}_{2}$ ratio in $\mathrm{Pt} / \mathrm{TiO}_{2} \mathrm{NF}$ catalysts should be carefully controlled. Zheng et al. [43] found that the maximum current densities in scans in the positive direction of the MOR in CV measurements decreased in the order $21 \% \mathrm{Pt} / \mathrm{TiO}_{2} \mathrm{NFs}>27 \% \mathrm{Pt} / \mathrm{TiO}_{2} \mathrm{NFs}>16 \%$ $\mathrm{Pt} / \mathrm{TiO}_{2} \mathrm{NFs}>10 \% \mathrm{Pt} / \mathrm{TiO}_{2} \mathrm{NFs}$. Therefore, the $21 \% \mathrm{Pt} / \mathrm{TiO}_{2} \mathrm{NFs}$ displayed the highest activity for the MOR with a peak current density of $1.781 \mathrm{~mA} / \mathrm{cm}^{2}$, which was about 1.6 times that of commercial Pt/C $\left(1.082 \mathrm{~mA} / \mathrm{cm}^{2}\right)$.

To further improve catalytic performance, researchers combined $\mathrm{TiO}_{2}$ substrates with carbon materials to enhance the electrical conductivity of Pt-based catalysts. These $\mathrm{Pt} / \mathrm{TiO}_{2}-\mathrm{C}$ catalysts synthesized by chemical vapor deposition, a microwave-assisted polyol process and photodeposition showed excellent electrochemical properties when tested under DMFC conditions $[44,45]$. For example, Fan's group [46] prepared $\mathrm{Pt} / \mathrm{TiO}_{2}-\mathrm{C}$ catalysts by reducing $\mathrm{H}_{2} \mathrm{PtCl}_{6}$ with $\mathrm{NaBH}_{4}$ on the $\mathrm{TiO}_{2}-\mathrm{C}$ particles. This $\mathrm{Pt} / \mathrm{TiO}_{2}-\mathrm{C}$ catalyst exhibited higher catalytic efficiency than commercial Pt/C catalyst in the MOR. Meanwhile, Yue et al. [47] proposed a $\mathrm{Pt}-\mathrm{TiO}_{2} / \mathrm{C}$ electrode containing $\mathrm{TiO}_{2}$ nanotubes $\left(\mathrm{TiO}_{2} \mathrm{NTs}\right)$, which were prepared by pyrolysis, and investigated its electrochemical performance in a DMFC. During the pyrolysis process, $\mathrm{H}_{2} \mathrm{PtCl}_{6}$ and glucose decomposed simultaneously to achieve an ideal dispersion effect and particle configuration. SEM images of the as-prepared $\mathrm{Pt} / \mathrm{TiO}_{2} \mathrm{NT}-\mathrm{C}$ electrode are shown in Fig. 8. This electrode exhibited superior catalytic efficiency and working stability compared with a Pt- $\mathrm{TiO}_{2} \mathrm{NT}$ electrode. The observed enhancement in the catalytic performance of the $\mathrm{Pt} / \mathrm{TiO}_{2} \mathrm{NT}-\mathrm{C}$ electrode was attributed to the smaller particle size, more homogeneous distribution, better dispersion and stronger interaction of interface electrons between $\mathrm{Pt}$ nanoparticles and the $\mathrm{TiO}_{2} \mathrm{NT}-\mathrm{C}$ support than in the $\mathrm{Pt}-\mathrm{TiO}_{2} \mathrm{NT}$ electrode.

For several years, researchers have focused on achieving higher activity of Pt- $\mathrm{TiO}_{2}$ catalysts by doping with other metallic or non-metallic elements [48,49]. Recently, Li et al. [50] reported that $\mathrm{Pt} / \mathrm{Ti}_{0.9} \mathrm{Sn}_{0.1} \mathrm{O}_{2}-\mathrm{C}$ showed enhanced electrocatalytic activity and durability compared with those of $\mathrm{Pt} / \mathrm{TiO}_{2}-\mathrm{C}$ and commercial $\mathrm{Pt} / \mathrm{C}$, as illustrated in Fig. 9. The improved performance was attributed to the presence of $\mathrm{Ti}_{0.9} \mathrm{Sn}_{0.1} \mathrm{O}_{2}$, in which the doped Sn increased the amount of adsorbed oxygen groups on the oxide surface, which aided the removal of $\mathrm{CO}_{\text {ads }}$ intermediates from the active sites. In addition, the unique 


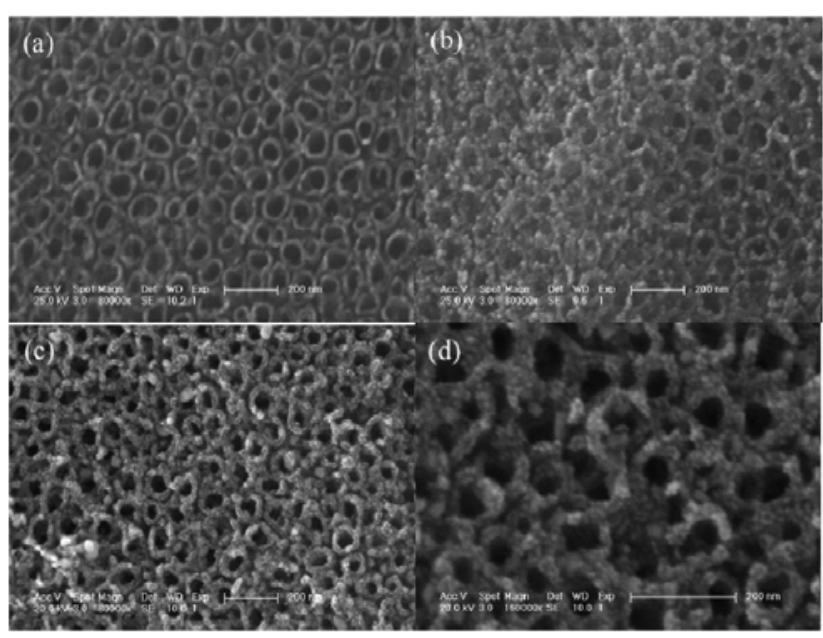

Fig. 8. SEM images of $\mathrm{TiO}_{2} \mathrm{NTs}(\mathrm{a}), \mathrm{Pt} / \mathrm{TiO}_{2} \mathrm{NTs}(\mathrm{b})$, and $\mathrm{Pt} / \mathrm{C} / \mathrm{TiO}_{2} \mathrm{NTs}$ (c, d) [47].

self-assembled $\mathrm{Ti}_{0.9} \mathrm{Sn}_{0.1} \mathrm{O}_{2}-\mathrm{C}$ structure provided junction deposition sites, allowing better dispersion of Pt nanoparticles.

A summary of the composition, structure, specific surface area, mass-normalized current density in the MOR and synthesis method of electrocatalytic materials developed for use in DMFCs is presented in Table 1 . The catalysts characterized under alkaline conditions such as $\mathrm{In}_{0.1} \mathrm{SnO}_{2}-\mathrm{Pt}$ and $\left(\mathrm{MoO}_{3}\right)_{0.2} \mathrm{SnO}_{2}$-Pt/C showed the best performance, but the acidic environment caused by the Nafion ionomer restricts their practicability in DMFCs. These catalysts are therefore not suitable for use in commercial fuel cells, unless researchers can make develop alkaline anion exchange membranes. Considering the rest of the reviewed catalysts, the Pt nanodendrites and Pt nanostars synthesized by the LLC template method achieved high electrocatalytic activities. However, it is difficult to expand the production scale of the LLC method to meet the require-

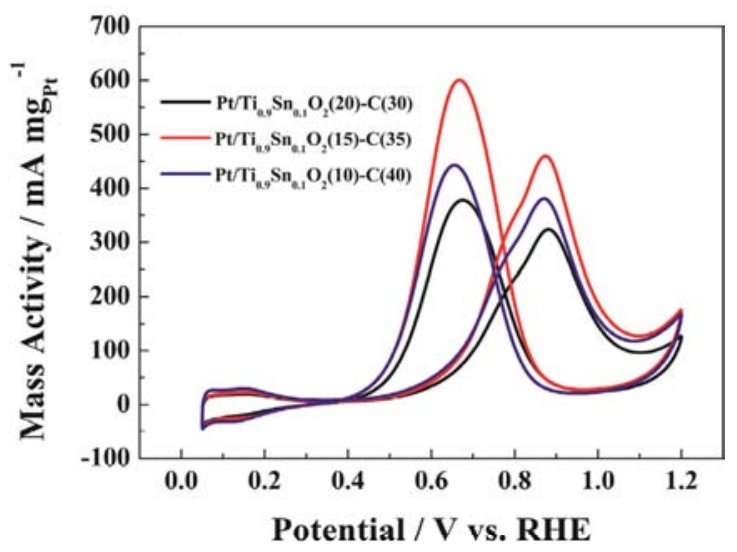

Fig. 9. $\mathrm{CV}$ curves of Pt supported on carbon black and $\mathrm{Sn}$-doped $\mathrm{TiO}_{2}$ in $0.5 \mathrm{~mol} / \mathrm{L}$ sulfuric acid $+0.5 \mathrm{~mol} / \mathrm{L}$ methanol [50].

ments of mass production. In addition, the stability of the redox potential and fuel atmosphere also affect the choice of catalyst. Therefore, Pt-based catalysts supported by transition metal oxides and carbon materials and synthesized by a relatively simple method, such as $\mathrm{Pt}-\mathrm{NRCeO}_{2} / \mathrm{GN}$ and $\mathrm{Pt} / \mathrm{Ti}_{0.9} \mathrm{Sn}_{0.1} \mathrm{O}_{2}-\mathrm{C}$, are potential candidates for DMFC application. Besides the development of novel structures and compositions, a thorough understanding of the reaction process in DMFCs is of utmost importance to achieve further advances. Further research efforts to improve the catalytic materials in DMFCs may focus on increasing catalyst durability.

\section{Development of high-efficiency electrocatalytic porous electrodes for use in DMFCs}

Several issues in DMFC research such as anode $\mathrm{CO}_{2}$ removal, cathode water flooding and MCO are still awaiting more effective resolutions. Notably, these issues are all related to the

Table 1

Summary of the composition, structure, specific surface area, mass-normalized current density in the MOR and synthesis method of catalysts for DMFCs.

\begin{tabular}{|c|c|c|c|c|c|}
\hline Composition & Structure & $\begin{array}{l}\text { Specific surface } \\
\text { area }\left(\mathrm{m}^{2} / \mathrm{g}\right)\end{array}$ & $\begin{array}{l}\text { Mass normalized current densi- } \\
\text { ties toward MOR }\left(\mathrm{mA} / \mathrm{mg}_{\mathrm{Pt}}\right)\end{array}$ & Synthesis method & Ref. \\
\hline Pt (Alfa Aesar) & Nanoparticle & 24 & 110 & Commercial & [9] \\
\hline $\mathrm{Pt}$ & Nanodendrite & 77 & 520 & LLC template & [9] \\
\hline $\mathrm{Pt}$ & Nanostar & 72 & 590 & LLC template & [9] \\
\hline $\mathrm{Pt}_{53} \mathrm{Cu}_{47}$ & Porous nano-network & 59.8 & 176 & Hydrothermal & [10] \\
\hline Pt-Pd & Hollow porous nanospheres & 23.3 & 204.6 & $\mathrm{SiO}_{2}$ nanospheres template & [12] \\
\hline $\mathrm{np}-\mathrm{Pt}_{3} \mathrm{Cu}_{1}$ & Ultrafine nanoporous alloy & 30 & 125.0 & Dealloying & [14] \\
\hline $\mathrm{Pt} / \mathrm{C}(\mathrm{E}-\mathrm{TEK})$ & Nanoparticle & 54.2 & 180 & Commercial & [20] \\
\hline $\mathrm{Pt}-\mathrm{Ru} / \mathrm{POBPC}$ & $\begin{array}{l}\text { Periodically ordered bimodal porous } \\
\text { carbon (POBPC) framework }\end{array}$ & 130 & 237.5 & Porous-solid template & [20] \\
\hline $\mathrm{Pt} / \mathrm{HNPHCS}$ & $\begin{array}{l}\text { Hierarchical nitrogen-doped porous } \\
\text { hollow carbon spheres (HNPHCS) with } \\
\text { porous-thin mesoporous shell and } \\
\text { hollow macroporous core }\end{array}$ & 805.23 & 336 & $\begin{array}{l}\text { In-situ oxidation polymeriza- } \\
\text { tion }\end{array}$ & [25] \\
\hline $\mathrm{Pt}-\mathrm{NR}_{\mathrm{CeO}} / \mathrm{GNs}$ & Rod-shaped $\mathrm{CeO}_{2}$ on graphene sheets & 72.6 & 498 & In situ growth & [32] \\
\hline $\mathrm{In}_{0.1} \mathrm{SnO}_{2}-\mathrm{Pt}$ & Nanoparticle & 43 & 2320 (in alkaline electrolyte) & Hydrothermal & [36] \\
\hline$\left(\mathrm{MoO}_{3}\right)_{0.2} \mathrm{SnO}_{2}-\mathrm{Pt} / \mathrm{C}$ & Nanoparticle & 47.4 & 4440 (in alkaline electrolyte) & Liquid phase precipitation & [37] \\
\hline $\mathrm{Pt} / \mathrm{TiO}_{2} \mathrm{NFs}$ & Nanofibers & 30.12 & 445.25 & $\begin{array}{l}\text { Electrospinning with reduc- } \\
\text { tive impregnation method }\end{array}$ & [43] \\
\hline $\mathrm{Pt} / \mathrm{TiO}_{2}-\mathrm{C}$ & Nanoparticle & 66.1 & 378.6 & Solvothermal method & [47] \\
\hline$\underline{\mathrm{Pt}} / \mathrm{Ti}_{0.9} \mathrm{Sn}_{0.1} \mathrm{O}_{2}-\mathrm{C}$ & Nanoparticle & 68.9 & 459.6 & Solvothermal method & [47] \\
\hline
\end{tabular}


structure parameters of the porous electrode in the MEA. Specifically, at both sides of the structural interface between the DL and CL, parameters such as porosity, topography and hydrophilicity are all different, and such differences can lead to large changes of transport properties over the entire MEA [51].

\subsection{Optimization of the mass transfer process}

As described above, the performance of DMFCs is strongly influenced by the mass transfer process in MEAs. Therefore, many researchers have attempted to develop mathematical models to help optimize the electrode design of DMFCs by comprehensively evaluating the effects of different structural parameters on DMFC performance. For instance, Yuan et al. [52] developed a multiphysics model coupled with mass and momentum transport that defined the methanol concentration, $\mathrm{CO}_{2}$ volume fraction and polarization curve. As shown in Fig. 10 , their simulation results indicated that the surface wettability of the anode DL determined the two-phase convection between $\mathrm{CO}_{2}$ and the methanol solution, and the optimal contact angle was $130^{\circ}$. Similarly, Sun and co-workers [53] developed a multiphase DMFC model to study the effect of microporous layers (MPLs) with different hydrophilicity properties on electrode performance. They found that as the contact angle increased along the flow direction of methanol in the anode DL, the liquid always needed to flow from a more hydrophilic region to a more hydrophobic one, leading to less MCO. The simulation results in Fig. 11 indicate that a higher anode DL contact angle generally led to more severe MCO, although it did increase the flow resistance at the inlet. In addition, the mass transport resistance at the DL/MPL interface was decreased, and the capillary-driven flow was enhanced inside the DL. However, because the MPL is very thin compared with the DL, it could act as a mass transfer barrier, mainly because of the contact angle differences across the MPL/DL and MPL/CL interfaces, which was the factor dominating the MPL function.

Weng et al. [54] experimentally investigated the MPL with a hydrophobic gradient at the cathode. Their experimental results revealed that the gradient MPL efficiently removed water from the electrode at high relative humidity. Liu and colleagues

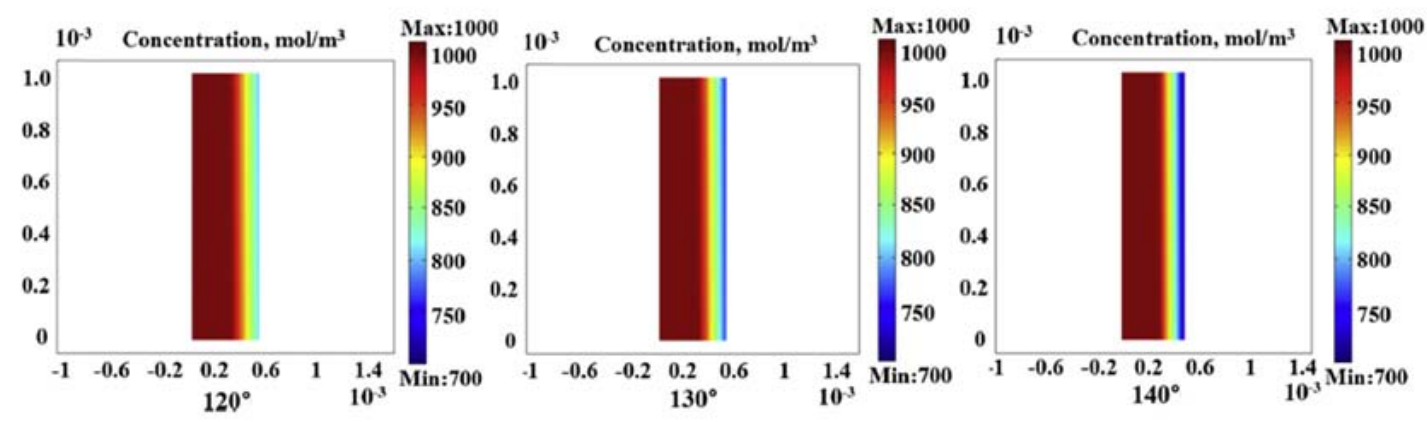

Fig. 10. Distribution of methanol concentration at the anode in a DMFC for different contact angles [52].
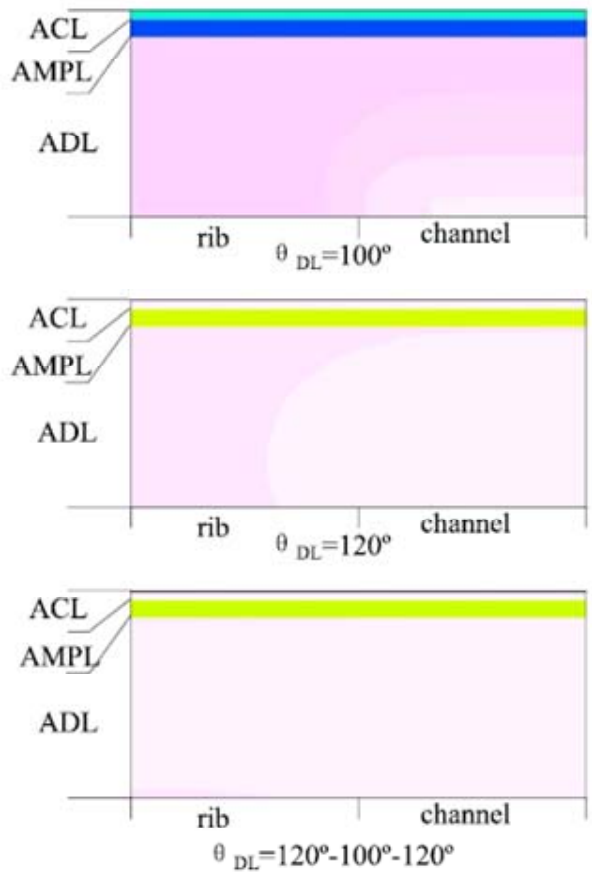
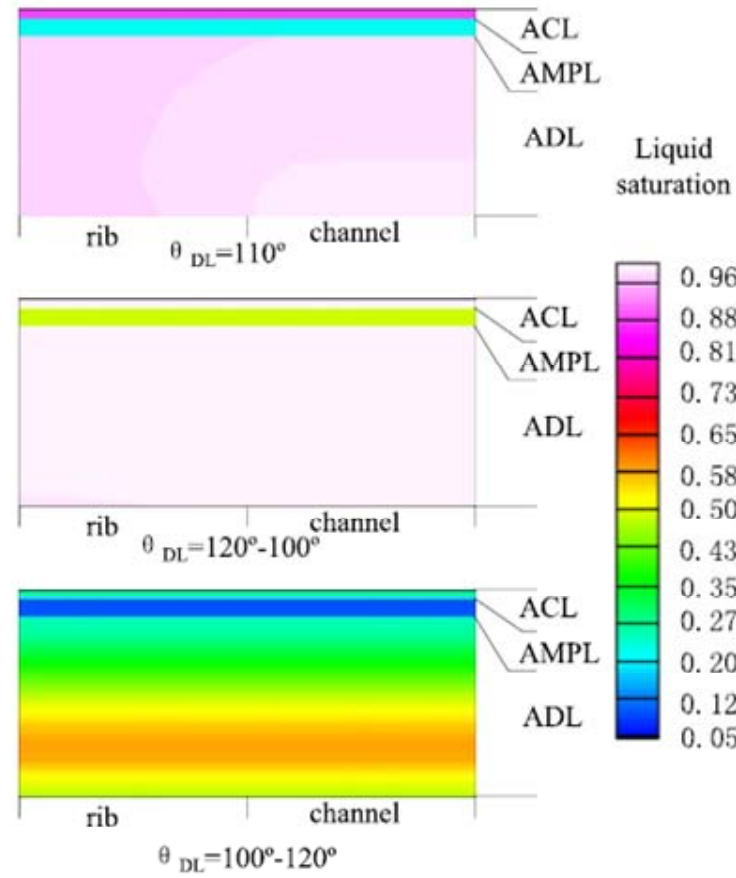

$\mathrm{ACL}$

AMPL

ADL

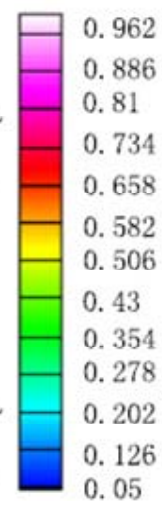

Fig. 11. Effect of DL contact angle on anode liquid saturation [53]. 
[55] compared several MEAs with different anode diffusion media, and concluded that the water transport coefficient through the membrane with a hydrophobic anode MPL was several times smaller than those of structures with a hydrophilic MPL or without an anode MPL.

Despite the advances achieved by this research, conventional MPLs made of carbon powder still suffer from the problem of cracks, which influence the permeability and capillary pressure of the electrodes. To tackle this issue, Yan et al. [56] proposed a MPL prepared with fluorinated carbon nanotubes (Fig. 12). The fluorinated nanotube MPL had no cracks and its contact angle was as high as $153^{\circ}$. Inclusion of the crack-free superhydrophobic MPL in a DMFC enabled a substantial increase in the water recovery flux, facilitated the MOR and thereby enhanced the cell performance. As a result, the maximum power density of the DMFC with the fluorinated nanotube MPL reached 25.6 $\mathrm{mW} / \mathrm{cm}^{2}$, an improvement of more than $30 \%$ compared with that of the DMFC containing carbon powder $\left(19.4 \mathrm{~mW} / \mathrm{cm}^{2}\right)$. Furthermore, the group proposed that the low surface energy of the material was the reason for its superhydrophobicity, and fluorine was effective to lower its surface free energy.

\subsection{Functional structure in MEAs}

In a working DMFC, if the products cannot be removed in time, they may occupy the effective reaction region and block the influx of reactants, leading to performance degradation. At present, especially when a DMFC is working under high current conditions, the efficiency of mass transportation in the MEA is still systemically inefficient. Therefore, MCO and how to effectively remove the products from the CL to the flow field are two urgent problems waiting for solution.

To solve the issue of MCO, many researchers have focused on the introduction of novel porous structures such as porous carbon plates or polymer films as a methanol control layer to adjust the total water flux and thus mitigate MCO $[57,58]$. Similarly, to improve product transportation, novel functional structures have been widely introduced into MEAs $[59,60]$. Structural modification of CLs had received widespread attention. In particular, CLs with a hydrophobic gradient distribution have been shown to enhance oxygen diffusion and water removal [61]. Meanwhile, 3D CLs with designed pore distributions that were prepared by depositing the catalyst on polypyrrole-treated polystyrene spheres have also exhibited facile $\mathrm{CO}_{2}$ removal [62]. Some CLs with functional multilayer structures have been developed. Liu et al. [63] prepared a bilayer anode CL with a relatively dense inner layer to mitigate

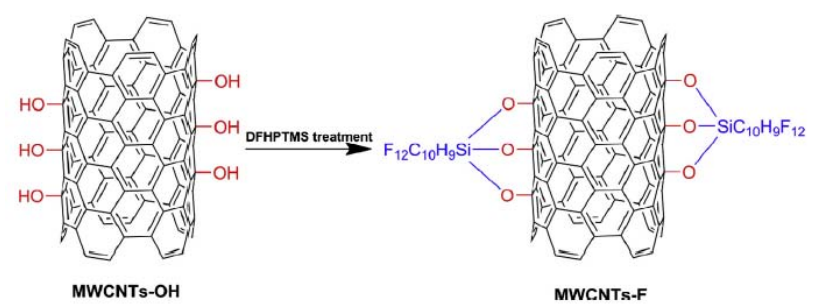

Fig. 12. Schematic illustration of the procedure used to prepare fluorinated multiwalled carbon nanotubes (MWCNTs) [56].

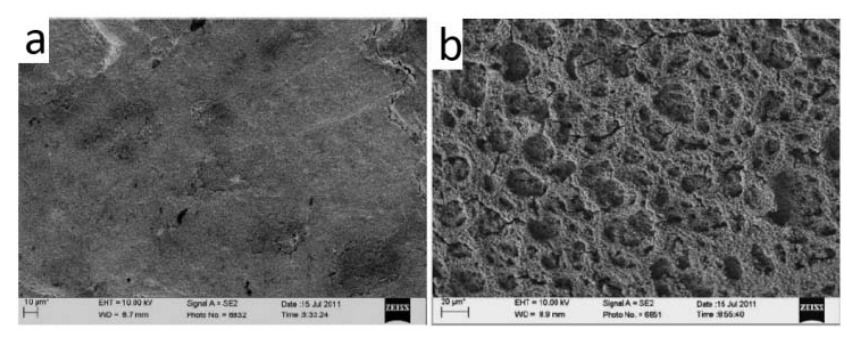

Fig. 13. SEM images of the inner CL (a) and outer CL (b) of a bilayer anode CL [63].

MCO, and a porous outer layer to meet the demands of the MOR. SEM images of the bilayer anode CL are shown in Fig. 13. The bilayer CL was prepared by an ultrasonic spray process that combined a catalyst-coated membrane transfer printing method with the direct spray technique. The performance improved from $116.8 \mathrm{~mW} / \mathrm{cm}^{2}$ for the traditional MEA to 202.6 $\mathrm{mW} / \mathrm{cm}^{2}$ for the optimized MEA at $80{ }^{\circ} \mathrm{C}$. Another bilayer CL with a hydrophilic PtRu black inner layer and PtRu/C outer layer was developed by Suo's group [64]. The advanced cell performance was attributed to the gradients of catalyst concentration and porosity in the catalyst, which led to higher conductivity of charged particles and more facile reactant/product transmission. Moreover, Zhao et al. [65] prepared a multilayer electrode by the sputtering method (Fig. 14). This electrode displayed favorable cell performance and mass activity because of the good contact at the interface between the catalyst and PEM and low mass transfer resistance.

Many investigations have indicated that a comparatively high porosity is beneficial to improve cell performance [66,67]. Introducing an appropriate amount of pore-forming additive during the preparation of the CL or MPL can improve cell performance [68]. Ammonium compounds that decompose at low temperature and acid-soluble oxide particles of appropriate sizes are both suitable for use as pore-forming agents in MEA modification because they can be entirely removed through heat treatment, hot pressing or acid washing [69,70]. However, these pore-forming agents always induced aggregation of catalyst particles during their removal, so the formed pores tended to be disordered and relatively independent, which could lower their correlative beneficial effects.

To further optimize the performance of DMFCs, Yuan et al. [71] presented a method for anode optimization using a gradient porous medium (Fig. 15) to realize more effective control of the anode mass transportation. This functional medium was composed of a self-developed metal fiber sintered felt based on multi-tooth cutting and high-temperature sintering. The assembly with a low-porosity layer installed inside performed better than that with a reverse setup. Their results highlight the advantage of using a horn-like structure to promote fast removal of the $\mathrm{CO}_{2}$ produced on the anode side, because it induced the formation of a pressure gradient that can help to drive $\mathrm{CO}_{2}$ more effectively out of the electrode. Similarly, Chai et al. [72] successfully fabricated a nano-network structure (NNS) within the anode CL and MPL of a MEA using zinc oxide (ZnO) as effective sacrificial template (Fig. 16). The maximum power density increased from $29.0 \mathrm{~mW} / \mathrm{cm}^{2}$ for the conven- 
(a)

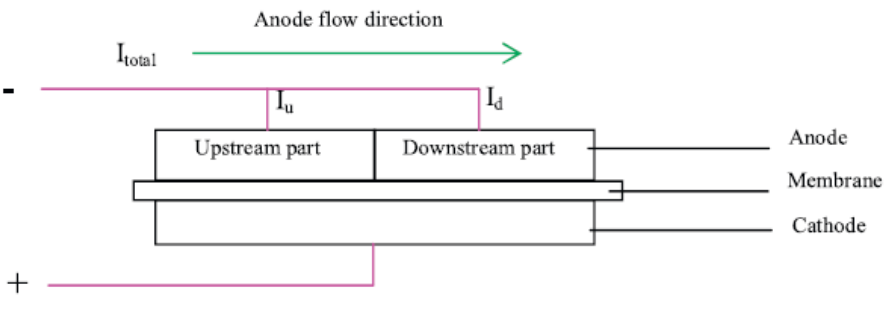

(b)

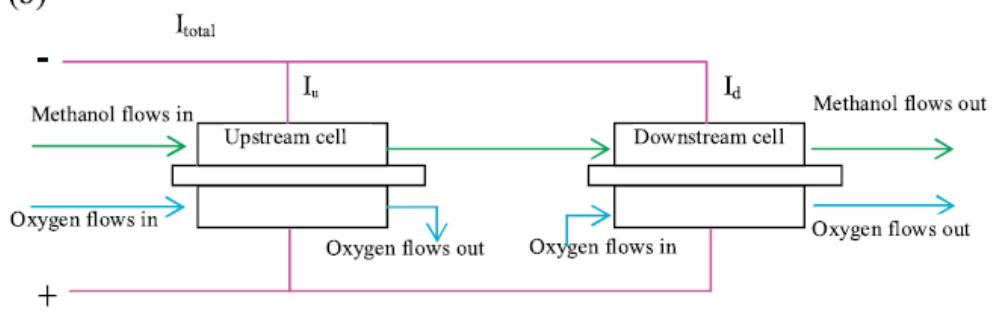

Fig. 14. Schematic diagrams of local current measurements with a single cell (a), and two cells simulated as a single cell (b) [65].

tional MEA to $40.2 \mathrm{~mW} / \mathrm{cm}^{2}$ for the optimized one. The improved performance of the MEA with the NNS was attributed to its higher catalyst utilization, higher mass transfer efficiency, and lower charge-transfer resistance compared with those of the conventional MEA. The connection of two network structures within different layers lowered the mass transfer resistance for methanol and water. However, the high content of water in the cathode strongly affected the reaction at the cathode and prevented the performance of the MEA from further improvement. This clearly indicates that the mass transfer on an anode could be improved considerably by the fabrication of a network structure. According to the results of EIS analysis (Fig. 17), the decrease in charge transfer resistance was one of the factors that could be responsible for the improvement in DMFC performance when a NNS was formed in the anode.

\section{Conclusions and outlook}
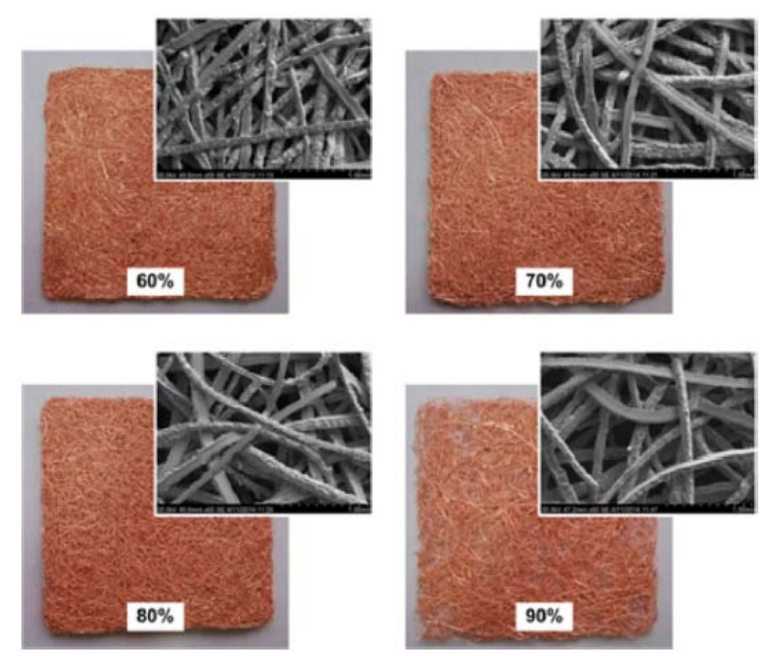

Fig. 15. Appearance and morphology of CFSF samples with different porosities [71].

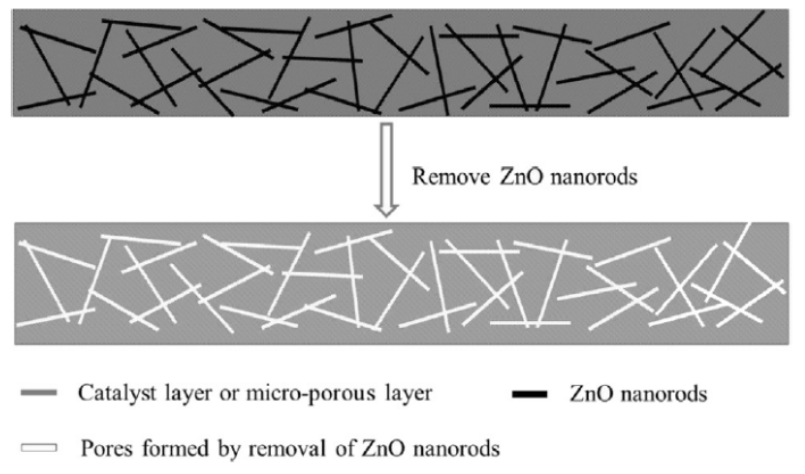

Fig. 16. Schematic illustration of the formation of a NNS using ZnO nanorods as a sacrificial template [72].
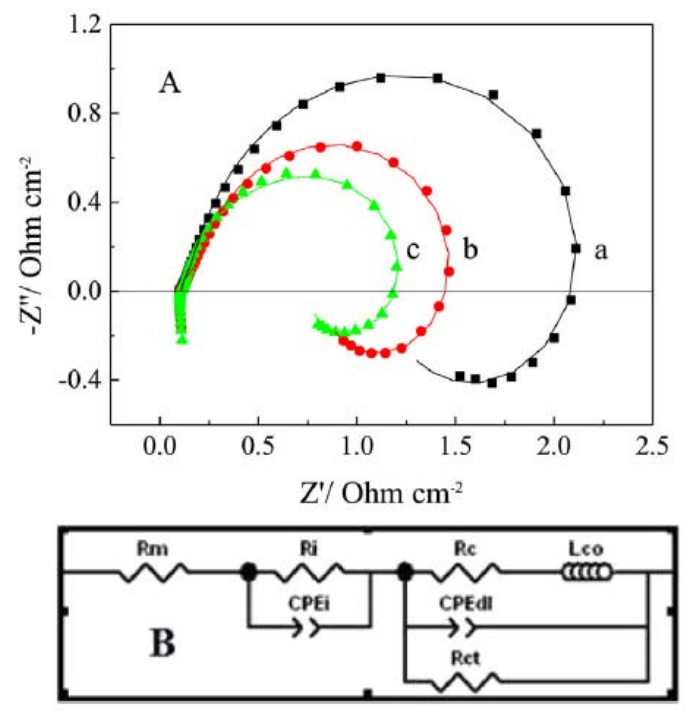

Fig. 17. EIS analysis (a) and equivalent circuit (b) of different anodes at a given DC potential of $0.4 \mathrm{~V} / \mathrm{DHE}$. (1) Conventional anode; (2) anode with a NNS CL with $20 \mathrm{wt} \% \mathrm{ZnO}$ nanorods; (3) anode with both a NNS CL and MPL formed with 20 wt\% $\mathrm{ZnO}$ nanorods with a Pt/Ru (1:1) loading of $2.0 \mathrm{mg} / \mathrm{cm}^{2}$ [72]. 
The electrocatalytic properties and mass transfer conditions of porous electrodes used in MEAs directly determine the power performance, stability and longevity of DMFCs. This review illustrates a variety of materials and structural modification methods for DMFCs reported recently. With the gradual expansion of related studies, the efficiency of electrocatalysis in DMFCs has been improved considerably. However, more work should be performed to clarify related mechanisms such as the reaction kinetics of multimetal catalysts, the functional principles of nanostructured supports, the adsorption mass transfer process at the MPL/CL interface and a practical MEA structure to allow inner water circulation. Accompanied with the accumulation of a complete theoretical system of DMFCs, additional breakthroughs to obtain important materials and continuous improvement of operating life, the prospects of DMFCs are bright.

\section{References}

[1] Z. D. Wei, S. H. Chan, J. Electroanal. Chem., 2004, 569, 23-33.

[2] S. K. Kamarudin, N. Hashim, Renew. Sust. Energy Rev., 2012, 16, 2494-2515.

[3] S. Sharma, B. G. Pollet, J. Power Sources, 2012, 208, 96-119.

[4] L. Giorgi, E. Salernitano, T. Dikonimos Makris, S. Gagliardi, V. Contini, M. De Francesco, Int. J. Hydrogen Energy, 2014, 39, 21601-21612.

[5] G. Caballero-Manrique, A. Velázquez-Palenzuela, E. Brillas, F. Centellas, J. A. Garrido, R. M. Rodríguez, P. L. Cabot, Int. J. Hydrogen Energy, 2014, 39, 12859-12869.

[6] L. Zhuang, J. Jin, H. D. Abruña, J. Am. Chem. Soc., 2007, 129, 11033-11035.

[7] Y. Xu, B. Zhang, Chem. Soc. Rev., 2014, 43, 2439-11035.

[8] Y. Yamauchi, A. Tonegawa, M. Komatsu, H. Wang, L. Wang, Y. Nemoto, N. Suzuki, K. Kuroda, J. Am. Chem. Soc., 2012, 134, 5100-5109.

[9] L. Wang, M. Imura, Y. Yamauchi, ACS Appl. Mater. Interfaces, 2012, 4, 2865-2869.

[10] Y. Fan, P. F. Liu, Z. W. Zhang, Y. Cui, Y. Zhang, J. Power Sources, 2015, 296, 282-289.
[11] B. H. Wu, N. F. Zheng, Nano Today, 2013, 8, 168-197.

[12] X. Y. Qiu, Y. X. Dai, X. S. Zhu, H. Y. Zhang, P. Wu, Y. W. Tang, S. H. Wei, J. Power Sources, 2016, 302, 195-201.

[13] L. X. Ding, A. L. Wang, G. R. Li, Z. Q. Liu, W. X. Zhao, C. Y. Su, Y. X. Tong, J. Am. Chem. Soc., 2012, 134, 5730-5733.

[14] J. Z. Sun, J. Shi, J. L. Xu, X. T. Chen, Z. H. Zhang, Z. Q. Peng, J. Power Sources, 2015, 279, 334-344

[15] Y. K. Yang, C. P. Han, B. B. Jiang, J. Iocozzia, C. G. He, D. Shi, T. Jiang, Z. Q. Lin, Mater. Sci. Eng. R, 2016, 102, 1-72.

[16] C. Chen, Y. J. Kang, Z. Y. Huo, Z. W. Zhu, W. Y. Huang, H. L. Xin, J. D. Snyder, D. G. Li, J. A. Herron, M. Mavrikakis, M. F. Chi, K. L. More, Y. D. Li, N. M. Markovic, G. A. Somorjai, P. D. Yang, V. R. Stamenkovic, Science, 2014, 343, 1339-1343.

[17] Y. H. Deng, J. Wei, Z. K. Sun, D. Y. Zhao, Chem. Soc. Rev., 2013, 42, 4054-4070.

[18] J. Sanetuntikul, T. Hang, S. Shanmugam, Chem. Commun., 2014, 50, 9473-9476.

[19] F. Zheng, G. Q. Mu, Z. M. Zhang, Y. O. Shen, M. J. Zhao, G. T. Pang, Mater. Lett., 2012, 68, 453-456.

[20] G. S. Chai, I. S. Shin, J. S. Yu, Adv. Mater., 2004, 16, 2057-2061.

[21] P. Song, L. D. Zhu, X. J. Bo, A. X. Wang, G. Wang, L. P. Guo, Electrochim. Acta, 2014, 127, 307-314.

[22] C. H. Choi, M. W. Chung, S. H. Park, S. I. Woo, Phys. Chem. Chem. Phys., 2013, 15, 1802-1805.

[23] Y. K. Zhou, K. Neyerlin, T. S. Olson, S. Pylypenko, J. Bult, H. N. Dinh, T. Gennett, Z. P. Shao, R. O'Hayre, Energy Environ. Sci., 2010, 3, 1437-1446.

[24] X. Tuaev, J. P. Paraknowitsch, R. Illgen, A. Thomas, P. Strasser, Phys. Chem. Chem. Phys., 2012, 14, 6444-6447.

[25] J. Zhang, L. Ma, M. Y. Gan, F. F. Yang, S. N. Fu, X. Li, J. Power Sources, 2015, 288, 42-52.

[26] P. O. Esteban, J. M. Leger, C. Lamy, E. Genies, J. Appl. Electrochem., 1989, 19, 462-464.

[27] K. R. Prasad, N. Munichandraiah, Synth. Met., 2002, 126, 61-68.

[28] H. J. Salavagione, J. Arias, P. Garcés, E. Morallón, C. Barbero, J. L. Vázquez, J. Electroanal. Chem., 2004, 565, 375-383.

[29] A. A. Ali Shah, N. Yasmeen, G. Rahman, M. Mehmood, S. Bilal, Electrochim. Acta, 2016, 188, 367-377.

[30] K. C. Cheung, W. L. Wong, D. L. Ma, T. S. Lai, K. Y. Wong, Coord. Chem. Rev., 2007, 251, 2367-2385.

[31] S. P. Yu, Q. B. Liu, W. S. Yang, K. F. Han, Z. M. Wang, H. Zhu, Electro-

\section{Graphical Abstract}

Chin. J. Catal., 2016, 37: 1037-1048 doi: 10.1016/S1872-2067(16)62477-4

Nanostructured electrocatalytic materials and porous electrodes for direct methanol fuel cells

Meng Wang, Xindong Wang *, Ming Chen, Zhaoyi Yang, Chaozhen Dong

University of Science and Technology Beijing

Nanostructured electrocatalytic materials and porous electrodes for use in direct methanol fuel cells are reviewed. The factors of composition, structure and enhancement mechanism are discussed.

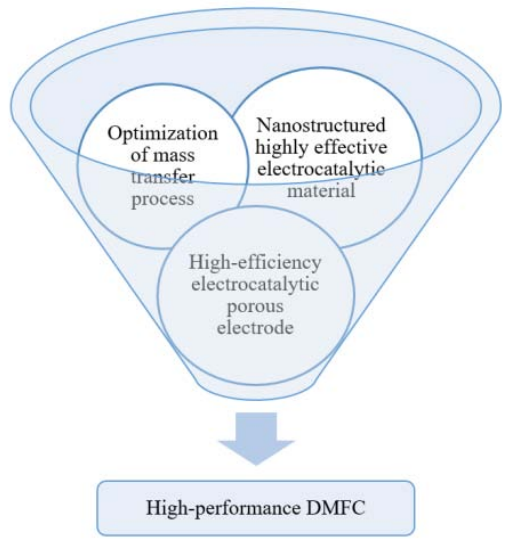


chim. Acta, 2013, 94, 245-251.

[32] W. H. Wang, X. L. Lu, M. D. Zhu, Z. Z. Cao, C. H. Li, Y. F. Gao, L. J. Li, J. R. Liu, Electrochim. Acta, 2015, 176, 1338-1342.

[33] M. X. Chen, C. C. Zhang, L. Z. Li, Y. Liu, X. C. Li, X. Y. Xu, F. L. Xia, W. Wang, J. P. Gao, ACS Appl. Mater. Interfaces, 2013, 5, 13333-13339.

[34] H. Q. Song, X. P. Qiu, F. S. Li Electrochim. Acta, 2008, 53, 3708-3713.

[35] R. M. Antoniassi, A. O. Neto, M. Linardi, E. V. Spinacé, Int. J. Hydrogen Energy, 2013, 38, 12069-12077.

[36] Y. Y. Feng, W. Q. Kong, Q. Y. Yin, L. X. Du, Y. T. Zheng, D. S. Kong, J. Power Sources, 2014, 252, 156-163.

[37] G. P. Lu, X. B. Ma, H. F. Yang, D. S. Kong, Y. Y. Feng, Int. J. Hydrogen Energy, 2015, 40, 5889-5896.

[38] J. Masud, M. T. Alam, Z. Awaludin, M. S. El-Deab, T. Okajima, T. Ohsaka, J. Power Sources, 2012, 220, 399-404.

[39] Y. Q. Huang, H. L. Huang, Q. Z. Gao, C. F. Gan, Y. J. Liu, Y. P. Fang, Electrochim. Acta, 2014, 149, 34-41.

[40] B. Hasa, E. Kalamaras, E. I. Papaioannou, L. Sygellou, A. Katsaounis, Int. J. Hydrogen Energy, 2013, 38, 15395-15404.

[41] X. W. Zhou, Y. L. Gan, J. J. Du, D. N. Tian, R. H. Zhang, C .Y. Yang, Z. X. Dai, J. Power Sources, 2013, 232, 310-322.

[42] H. Chen, S. X. Wang, W. L. Zhao, N. N. Zhang, Y. P. Zheng, Y. M. Sun, Acta Phys. Chim. Sin., 2015, 31, 302-308.

[43] Y. P. Zheng, H. Chen, Y. Q. Dai, N. N. Zhang, W. L. Zhao, S. X. Wang, Y. B. Lou, Y. Li, Y. M. Sun, Electrochim. Acta, 2015, 178, 74-79.

[44] B. Abida, L. Chirchi, S. Baranton, T. W. Napporn, H. Kochkar, J. M. Léger, A. Ghorbel, Appl. Catal. B, 2011, 106, 609-615.

[45] Z. Z. Jiang, Z. B. Wang, W. L. Qu, D. M. Gu, G. P. Yin, Appl. Catal. B, 2012, 123-124, 214-220.

[46] Y. Fan, Z. J. Yang, P. Huang, X. Zhang, Y. M. Liu, Electrochim. Acta, 2013, 105, 157-161.

[47] X. Y. Yue, W. X. Yang, X. J. Liu, Y. Z. Wang, C. Y. Liu, Q. Y. Zhang, J. B. Jia, Electrochim. Acta, 2015, 174, 667-671.

[48] Y. Gu, C. T. Liu, Y. B. Li, X. L. Sui, K. Wang, Z. B. Wang, J. Power Sources, 2014, 265, 335-344.

[49] X. T. Liu, X. Wu, K. Scott, Catal. Sci. Technol., 2014, 4, 3891-3898.

[50] Y. B. Li, C. T. Liu, Y. Y. Liu, B. Feng, L. Li, H. Y. Pan, W. Kellogg, D. Higgins, G. Wu, J. Power Sources, 2015, 286, 354-361.

[51] H. Meng, Int. J. Hydrogen Energy, 2010, 35, 5569-5579.

[52] Z. Y. Yuan, J. Yang, Y. F. Zhang, S. K. Wang, T. N. Xu, Energy, 2015,
93, 599-605.

[53] J. Sun, T. Guo, H. Deng, K. Jiao, X. R. Huang, Int. J. Hydrogen Energy, 2015, 40, 10568-10587.

[54] F. B. Weng, C. Y. Hsu, M. C. Su, Int. J. Hydrogen Energy, 2011, 36, 13708-13714.

[55] M. Zago, A. Casalegno, F. Bresciani, R. Marchesi, Int. J. Hydrogen Energy, 2014, 39, 21620-21630.

[56] X. H. Yan, T. S. Zhao, L. An, G. Zhao, L. Zeng, Appl. Energy, 2015, 138, 331-336.

[57] G. C. Liu, M. Wang, Y. T. Wang, F. Ye, T. T. Wang, Z. Tian, X. D. Wang, Int. J. Hydrogen Energy, 2012, 37, 8659-8663.

[58] W. Yuan, Z. C. Zhang, J. Y. Hu, B. Zhou, Y. Tang, Appl. Energy, 2014, 136, 143-149.

[59] Y. C. Park, D. H. Kim, S. Lim, S. K. Kim, D. H. Peck, D. H. Jung, Int. J. Hydrogen Energy, 2012, 37, 4717-4727.

[60] R. Fiala, M. Vaclavu, M. Vorokhta, I. Khalakhan, J. Lavkova, V. Potin, I. Matolinova, V. Matolin, J. Power Sources, 2015, 273, 105-109.

[61] M. Chen, J. Chen, Y. Li, Q. H. Huang, H. F. Zhang, X. Z. Xue, Z. Q. Zou, H. Yang, Energy Fuels, 2012, 26, 1178-1184.

[62] F. Y. Xie, H. Meng, P. K. Shen, Electrochim. Acta, 2008, 53, 5039-5044.

[63] G. C. Liu, M. Wang, Y. T. Wang, Z. Tian, X. D. Wang, Int. J. Energy Res., 2013, 37, 1313-1317.

[64] C. G. Suo, W. B. Zhang, H. Wang, G. M. Wu, Adv. Mater. Res., 2013, 652-654, 819-822.

[65] G. Zhao, T. S. Zhao, X. H. Yan, L. Zeng, Electrochim. Acta, 2015, 164, 337-343.

[66] N. K. Shrivastava, S. B. Thombre, R. K. Mallick, Electrochim. Acta, 2014, 149, 167-175.

[67] Y. T. Wang, L. Zheng, G. M. Han, L. X. Lu, M. Wang, J. L. Li, X. D. Wang, Int. J. Hydrogen Energy, 2014, 39, 19132-19139.

[68] G. C. Liu, X. N. Ding, H. W. Zhou, M. Chen, M. X. Wang, Z. X. Zhao, Z. Yin, X. D. Wang, Appl. Energy, 2015, 147, 396-401.

[69] Q. H. Huang, J. J. Jiang, J. S. Chai, T. Yuan, H. F. Zhang, Z. Q. Zou, X. G. Zhang, H. Yang, J. Power Sources, 2014, 262, 213-218.

[70] Y. Lee, T. K. Kim, Y. S. Choi, Fuel Cells, 2013, 13, 173-180.

[71] W. Yuan, Z. G. Yan, Z. H. Tan, A. Y. Wang, Z. T. Li, Y. Tang, Renew. Energy, 2016, 89, 71-79.

[72] J. S. Chai, Y. Zhou, J. Fan, J. J. Jiang, T. Yuan, H. F. Zhang, Z. Q. Zou, H. D. Qian, H. Yang, Int. J. Hydrogen Energy, 2015, 40, 6647-6654.

\title{
直接甲醇燃料电池纳米结构电催化材料及多孔电极研究
}

\author{
王 萌, 王新东, 陈 明, 杨兆一, 董超振 \\ 北京科技大学冶金与生态工程学院物理化学系, 北京100083
}

摘要: 直接甲醇燃料电池(DMFC)因其燃料能量密度高, 工作温度低, 低污染排放等优点被认为是用作移动设备电源的最 佳选择之一, 至今已有美国的Oorja Protonics公司和丹麦的IRD公司等新能源相关企业相继发布了多款用于手机、电脑、通 信基站、叉式装卸机或房车的商业产品. 然而, DMFC内部的复杂情况造成的多种不同的电压损失仍旧使得其实际电压效 率远低于理论值. 其中从阳极渗透到阴极的甲醇造成的混合电位导致的电压损失尤为明显. 目前, 众多研究人员都致力于 开发高稳定性、高耐久性、高性能且低成本的催化材料体系, 以克服传统Pt催化剂存在的各种问题. 除了催化剂本身之外, DMFC的问题还与其中膜电极的微结构和电化学特性息息相关. 膜电极是化学能通过电催化氧化还原反应转化为电能的 反应场所, 通常由阳极扩散层、阳极催化层、质子交换膜、阴极催化层和阴极扩散层依序组合而成. 通过对MEA中的各层 进行优化, 如传质管理和甲醇渗透等问题都能得到有效解决.

近年来, 纳米技术常被用于改进DMFC性能的研究. 具备纳米结构的金属-碳/金属氧化物载体类催化材料得到了广泛 研究. 这些电催化材料在制备方法、结构和组分上都有较大区别. 结构方面, 许多研究都证明制备纳米级多孔网络结构或 者有序阵列结构的催化层有助于提高催化性能和Pt的利用率. 组分方面, 许多研究人员都开展了引入Pt以外金属成分或金 
属氧化物来改变Pt催化剂的表面电子状态的研究. 引入这些组分导致的配位体效应可以通过弱化 $\mathrm{Pt}$ 与 $\mathrm{H}^{+}, \mathrm{OH}^{-}$或 $\mathrm{CO}_{\mathrm{ads}}$ 等的 相互作用来起到抗催化毒化和提高催化效率的作用. 尽管对于DMFC领域的认知逐渐完善, 但是仍有许多问题有待解决. 因此, 本文介绍了目前用于DMFC的纳米结构电催化材料和多孔电极的研究进展. 重点介绍了纳米结构催化剂和载体材料 的合成及表征.

通过对比不同催化材料的特性可以发现, 在本文涉及到的催化材料中, $\mathrm{In}_{0.1} \mathrm{SnO}_{2}-\mathrm{Pt}$ 和 $\left(\mathrm{MoO}_{3}\right)_{0.2} \mathrm{SnO}_{2}-\mathrm{Pt} / \mathrm{C}$ 表现出了最高 的催化活性, 但是它们高效催化甲醇电氧化所需的碱性环境与现在占绝对主流地位的Nafion质子交换膜所必须的酸性环 境相冲突, 所以其实际应用价值在碱性阴离子交换膜研究取得突破前都难以有效发挥. 而另一类表现较好的采用溶致液 晶模板法合成的纳米树枝状和纳米星形Pt催化剂则存在制备工艺难以商业规模化的问题. 总的来说, 采用溶剂热合成法制 备的Pt- $\mathrm{NR}_{\mathrm{R}} \mathrm{CeO}_{2} / \mathrm{GNs}$ 和 $\mathrm{Pt} / \mathrm{Ti}_{0.9} \mathrm{Sn}_{0.1} \mathrm{O}_{2}$-C等纳米结构金属氧化物、碳材料复合载体和Pt基贵金属催化剂组成的催化材料体系 不仅催化性能相对于商业化Pt纳米颗粒有很大提高, 而且制备方法易于商业规模化, 值得进一步关注. 此外, 本文还介绍了 如内部传质过程的理论建模计算和膜电极中功能结构的制备等优化DMFC中多孔电极内传质过程的方法. 通过计算机模 拟得到优化DMFC内部传质过程所需的扩散层、催化层的传质特性相关参数, 再通过改进MEA制备工艺, 有效控制各层的 结构参数向模拟的优化值靠拢, 能够实现DMFC性能的有效提升. 综合模拟、实验研究及工艺研究结果, 根据实际需要, 设 计和制备包含新功能层的MEA的相关研究也更进一步提高了DMFC的性能和实用性. 就目前的研究情况而言, 如果在性 能提升的基础上, 使用寿命再取得突破, DMFC一定会有很好的商业应用前景.

关键词: 催化剂; 多孔电极; 甲醇渗透; 电催化性能; 膜电极; 直接甲醇燃料电池

收稿日期: 2016-04-22. 接受日期: 2016-05-27. 出版日期: 2016-07-05.

*通讯联系人. 电话/传真: (010)62332651; 电子信箱: echem@ustb.edu.cn

基金来源：国家自然科学基金(51274028).

本文的英文电子版由Elsevier出版社在ScienceDirect上出版(http://www.sciencedirect.com/science/journal/18722067). 